\title{
Who is responsible? Local government and accountability for service delivery in Kenya's devolved health sector
}

\section{Commonwealth Journal of Local Governance}

Issue 20: December 2017

http://epress.lib.uts.edu.au/ojs/index.php/cjlg

\author{
Kenneth Okwaroh Ochieng \\ Africa Centre for People Institutions and Society \\ Nairobi \\ Kenya \\ Email: okwaroh@acepis.org
}

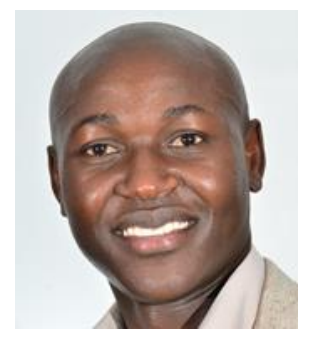

\begin{abstract}
One of the arguments in favour of local governments is their ability to deliver public services better because of their proximity to demand. This is typically achieved through decentralisation - the transfer of some level of formal responsibility, authority and/or resources to smaller, lower tiers of government. This paper examines service delivery in the health sector in Kenya within the context of the country's newly introduced devolved system of government, which created 47 county governments under the 2010 Constitution. It examines three key responsibilities: i) resource mobilisation, distribution and administration, ii) decision-making, and iii) political accountability, and their bearing on outcomes for delivery of health services. The paper argues that devolution of the health function in Kenya has been only partial, leading to challenges of coordination between the national and county governments and ambiguity over responsibility for service delivery; both factors which risk undermining the opportunities that devolution creates or promises.
\end{abstract}

\section{Introduction}

One of the arguments in favour of local-level government is that it can better deliver public 'goods' because of its proximity to demand (Duncan 2004; Rao et al. 2014). Local governments can achieve quicker service delivery than centralised systems and gain more trust from citizens because they operate closer to the public and are more visible, accessible and accountable (Devas et al. 2008; Rao et al. 2014). Local-level governance is based on the concept of decentralisation: the transfer of some level of formal responsibility, authority and/or resources to smaller, lower units of government - usually counties,

DOI: http://dx.doi.org/10.5130/cjlg.v0i20.6085

Article History: Received 18/07/2015; Accepted 26/08/17; Published 23/05/18

Citation: Commonwealth Journal of Local Governance 2017, 20: 6085, - http://dx.doi.org/10.5130/cjlg.v0i20.6085

(c) 2018 Kenneth Okwaroh Ochieng. This is an Open Access article distributed under the terms of the Creative Commons Attribution 4.0 Unported (CC BY 4.0) License (https://creativecommons.org/licenses/by/4.0/), allowing third parties to copy and redistribute the material in any medium or format and to remix, transform, and build upon the material for any purpose, even commercially, provided the original work is properly cited and states its license. 
districts, regions or states (Duncan 2004; Saltman et al. 2007). Such decentralisation may take different forms, including deconcentration, devolution, delegation and privatisation (Duncan 2004; Vrangbaek 2007; Devas et al. 2008).

The existing literature on decentralisation and service delivery indicates that decentralisation can offer considerable advantages, although there is limited empirical evidence of positive outcomes (Smoke 2015). Advantages identified include greater effectiveness in mobilisation and efficiency in allocating resources (Devas 2005; Rao et al. 2014), deeper citizen participation (Blair 2000; Wong and Guggenheim 2006; Devas et al. 2008), and improved accountability mechanisms (Devas 2005; Lessmann and Markwardt 2009; Yilmaz et al. 2010).

However, the literature also suggests that decentralisation has not been an easy route to effective service delivery, as it involves complex processes that influence quality and coverage of services (Wunsch 2001; Olowu 2003; Duncan 2004). For example, there are occasions when roll-outs of decentralisation programmes have faced rejection or resistance by sectoral/line ministries of national/central governments (Olowu 2003; Devas et al. 2008; Boex 2009). In other circumstances, the time-lag between in-principle decentralisation and its implementation has contributed to poor performance and sparked resentment from the public. Elsewhere, lack of experience amongst local elected leaders and the effects of electoral politics (for example a culture of patronage, or the capture of elected local governments by different interest groups) have also hampered the effectiveness of decentralised service delivery (Acosta et al. 2013).

Notable successes, however, indicate that decentralisation can be very beneficial when actors address both the supply and demand sides of service delivery (UNCDF 2010): for example, when capacity development takes place within local and national governments in parallel, allowing local governments to maximise their autonomy while receiving support to balance local responsibilities with local discretion; or when local service delivery competencies are matched with adequate funding (Wunsch 2001; Duncan 2004; UNCDF 2005).

This paper examines the framework for service delivery in the health sector in Kenya, within the context of the country's newly introduced devolved system of government - county governments. The paper is based on a literature review of academic papers, reports by civil society organisations working on devolution, media accounts and analyses of constitutional devolution in Kenya. It examines three mandates devolved to county governments and their bearing on outcomes for delivery of services in the health sector. These mandates are i) resource mobilisation and distribution ii) decision-making and iii) political accountability. 


\section{Analytical framework}

Achieving smooth working relations between decentralised and national/central governments, with effective accountability and coordination mechanisms, is crucial for service delivery. Nonetheless, experience across the globe often finds such relations characterised by mistrust and wrangling, with the main source of tension being the tendency of central or national governments to exert excessive control, yet still expect high standards of accountability from decentralised units of government (Wunsch 2001; Crook 2003; Olowu 2003; Panday 2006; Rao et al. 2014). Some scholars maintain, understandably, that central governments are justified in their desire to remain involved in the affairs of decentralised units, in order to ensure accountability and prudent use of public resources (Olowu 2003; Crook 2003; Panday 2006; Boex 2009). However, others argue that national/central government involvement is only useful if it does not undermine local authority ${ }^{1}$ (Wunsch 2001; Delay 2008).

From this tension, two key questions arise: 1) Do decentralised units of government need more autonomy in order to deliver services better, innovate boldly and be more accountable? and 2) What accountability mechanisms, both downwards to citizens and upwards to national/central governments, can allow them that autonomy while still engaging effectively with other tiers of government?

The following analysis discusses the relationship between decentralised units of government and the national government (and independent national institutions) within the context of healthcare service delivery in Kenya. It explores issues of coordination and perceived responsibility for service delivery between national and county governments and considers their implications for achieving good outcomes at county government level. To do this, it examines relations between the two levels of government in three areas of responsibility: i) resource mobilisation, distribution and administration ii) decisionmaking and iii) overall political accountability.

As illustrated in Figure 1, Kenya's devolved system of government is a synthesis of the previous centralised system of government, collapsing eight provincial administrations to create 47 county governments, which now oversee areas previously covered by 175 local authorities, 280 deconcentrated local administrative units and 280 district administrations (Mwenda 2010; World Bank, 2011; Murkomen 2012). The health function is one whose responsibility has been transferred to county governments, but with some level of responsibility retained by the national Ministry of Health (Murkomen 2012).

\footnotetext{
${ }^{1}$ Simon Delay points out that there is a fine line between excessive regulation and autonomy of local governments (Delay 2008):

https://www.researchgate.net/profile/Munawwar_Alam2/publication/280317403_Financing_Local_Government /links/5764410508aedbc345ecc054/Financing-Local-Government.pdf?origin=publication_detail
} 
Figure 1: How the county governments were formed

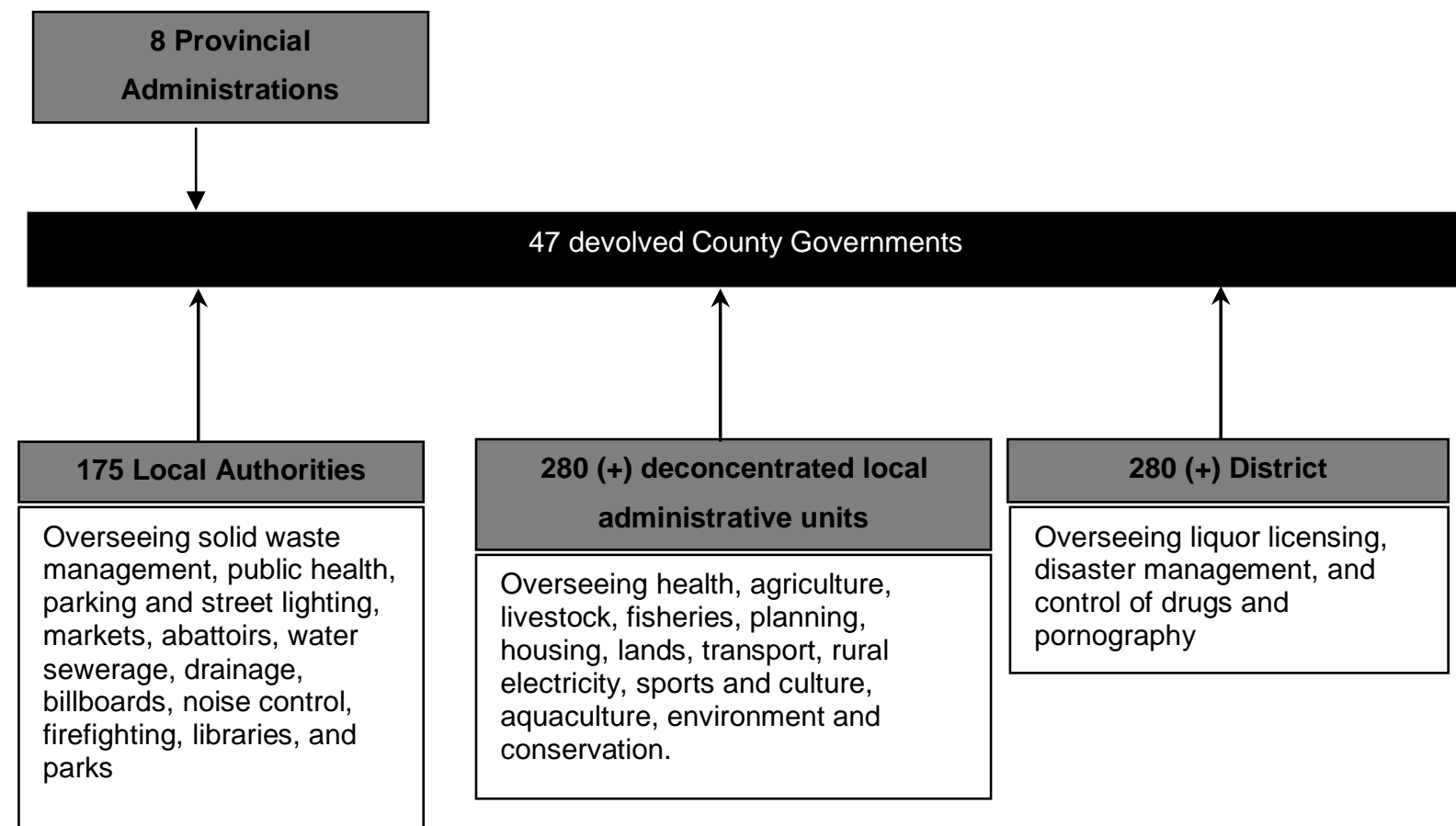

Source: World Bank (2011)

\section{Analysis and discussion}

\section{Resource mobilisation, distribution and administration}

Decentralised units of government are argued to be able to develop plans and programmes based on local needs and resources, and implement such programmes taking into account issues of political and social and economic marginalisation (Fjeldstad et al. 2006; Boex 2009; Rao et al. 2014). Some researchers have also argued that fiscal decentralisation could drive inclusive economic growth and promote sustainable development in localities traditionally bypassed by centralised governments (Shah 2007; Devas et al. 2008).

However, in order for decentralised units of government to effectively deliver services and accrue the benefits of decentralisation, adequate financing is necessary (Shah 2007; Devas et al. 2008; Rao et al. 2014). This is actualised through fiscal decentralisation - the process of assigning not only financial resources to sub-national or local governments, but also the authority to make decisions on the management and application of, and accountability for, such resources (Duncan 2004; Devas et al. 2008; Boex 2009; Rao et al. 2014).

The revenues that decentralised units of government spend on delivering services come from three main sources. The first is intergovernmental fiscal transfers (IFTs) - monies sent from national/central governments to local authorities to fund their programmes and activities (Bird and Smart 2001; Duncan 2004; Devas et al. 2008; Boadway and Shah 2007; Boex 2009; Alam 2014). The second is local collections - taxes, charges and other receipts which local governments are allowed to levy (Duncan 
2004; Blore et al. 2004; Devas et al. 2008). The third is external revenues - mainly loans ${ }^{2}$ and grants obtained from external governments and/or financial institutions (Duncan 2004; Plekhanov and Singh 2007).

For decentralised units of government to benefit from any of these sources, deliberate and substantial concessions, in terms of both fiscal legislation and economic policy management, have to be made by national/central governments (Boex 2009). These are prerequisites for fiscal decentralisation to work and to enable local governments to deliver services. Such concessions must allow decentralised units of government a proportion of resources available at national level, commensurate with the amount of service delivery decentralised (Wunsch 2001; Devas et al. 2008). The concessions must also allow sufficient autonomy for local governments to design and execute local tax regimes adapted to the circumstances of the local population but also capable of attracting the revenues they require (Tanzi 2001; Wunsch 2001; Fjeldstad et al. 2014). Furthermore, national governments must allow them some legal space to effectively negotiate with international partners regarding grants or loans (Plekhanov and Singh 2007; Devas et al. 2008). Lastly, national/central governments must institutionalise effective mechanisms for developing the capacity of decentralised units of government - for example in public financial management - to efficiently administer and account for resources (Wunsch 2001; UNCDF 2005; Fjeldstad et al. 2006; Rao et al. 2014).

In Kenya, the framework for fiscal decentralisation has been characterised by wrangling between the national and county governments over their roles in mobilisation, distribution and accountability for health financing. There have been multiple reports in local media of tussles between county governors, through the Council of Governors, ${ }^{3}$ and the national Treasury and Controller of Budgets over the freedom of county governments to borrow, attract grants and design tax regimes to generate more of their own financial resources (Were 2017). This wrangling has made it difficult to assign responsibility for the inadequacy of resources for health financing notable in many parts of the country. Although Kenya is a signatory to the Abuja Declaration of 2001, which commits the country to allocating at least $15 \%$ of national resources to the health sector, the national average expenditure on health has remained at about $6 \%$ over the past decade (although some counties have reported significant improvements) (Maina et al. 2016; Ochieng et al. 2015; Nesoba 2014). Overall, most counties report a per capita expenditure on health lower than the benchmarks set by the High-level Taskforce on Innovative International Financing for Health Systems (\$86/head), or the Commission on Macroeconomics and Health (\$71/head), for providing comprehensive health services in low-income countries (McIntyre and

\footnotetext{
${ }^{2}$ Strictly speaking, however, borrowing should be regarded as a financing mechanism rather than a revenue source, since the funding is intended to be repaid.

${ }^{3}$ The Council of Governors is an umbrella organisation of all the 47 County Governments in Kenya established under Section 19 of the Intergovernmental Relations Act (Council of Governors, 2018). It provides a platform for county governments to among other things, collectively consult on devolution matters.
} 
Meheus 2014; Maina et al. 2016). The figures illustrate a significant shortfall in resources for delivering healthcare services. Additionally, the existing disparities between counties are exacerbated by varying decisions on the proportion of county government resources to allocate to health (Netherlands Enterprise Agency 2016). However, such disparities are a well-known and inevitable feature of decentralisation, since each area has autonomy to set its own priorities.

Whilst Kenya's constitution provides that responsibility for health service delivery shall be transferred to county governments, together with the necessary resources, there is little clarity as to the amount of resources or the level of responsibility transferred. ${ }^{4}$ A national independent commission (the Commission on Revenue Allocation) presides over the distribution of revenues between national and county governments, and between the 47 county governments. However, the actual transfers of resources are carried out by the Treasury, a department which has been the focus of tussles between the counties and national government over how much to transfer, when to transfer, and under what circumstances to transfer (Were 2017). ${ }^{5}$ For instance, the chairperson of the Commission for the Implementation of the Constitution (CIC) indicated in 2015 that delays in the transfer of functions and funds was frustrating service delivery (Anami 2015). Further, in 2016 there were reports of financial crises faced by county governments due to delays in disbursement of funds by the national government (Wakhisi 2016). The outcome has been inefficiencies in procurement that have had devastating implications for availability of drugs at hospitals, remuneration of personnel, and the volume and standards of health facilities in many counties. ${ }^{6}$

The national government attributes the delays and inefficiencies to a failure of county health management teams to comply with Treasury's fund management and administrative requirements. County governments on the other hand argue that it is the responsibility of national government to put the requisite systems and structures in place to facilitate fiscal decentralisation (Anami 2015). They also argue that the inadequacy of systems must not be used by the national government as an excuse to limit the fiscal powers of county governments and restrict access to resources earmarked for service delivery at county level (Anami 2015).

The net effect has been a lack of drugs and other healthcare commodities in hospitals, insufficient health facilities, and health workers going for months without salary. For example, there have been protracted

\footnotetext{
${ }^{4}$ Part 2 of the fourth schedule of the Constitution of Kenya 2010 merely outlines provision of health services as part of the functions and powers of the county governments:

http://kenyalaw.org/lex/rest//db/kenyalex/Kenya/The\%20Constitution\%20of\%20Kenya/docs/ConstitutionofKen ya\%202010.pdf

${ }^{5}$ This is contingent on economic governance and public finance management regulations/laws - PFM Act 2012: http://www.treasury.go.ke/tax/acts.html?download=603:the-public-finance-management-act-2012-1-1

${ }^{6}$ The CIC has pointed to unjustified delays in transfer of devolved functions and funds (Anami 2015): http://www.standardmedia.co.ke/article/2000147930/delay-in-transfer-of-functions-affecting-constitutionimplementation-says-charles-nyachae
} 
industrial disputes that have paralysed health service delivery, caused by disagreements between national and county governments on suitable remuneration packages for health sector personnel (Muriuki et al. 2015; Netherlands Enterprise Agency 2016; Aljazeera 2017; Otenyo 2017). For ordinary citizens seeking medical attention, the responsibility seems to lie squarely with the county governments, mandated by the constitution to provide healthcare. Yet the intricacies of the process of decentralising resources mean the situation is not that straightforward (Were 2017). County governments cannot deliver services without resources; but the public is told by national government that resources have been provided to county governments - yet without explaining the shortcomings of the system of fiscal decentralisation.

Over the first two years of devolution in Kenya, county governments performed worse at local revenue collection than the former local authorities ${ }^{7}$ (Okulo 2014; Were 2017). This outcome appeared partly due to capacity challenges, according to the Council of Governors' statutory report for 2014-15 (Council of Governors 2016). This view is echoed by the Institute of Certified Public Accountants of Kenya (ICPAK), which also notes that capacity limitations regarding collection and accounting for local revenues continue to limit own-revenue generation at county levels (ICPAK 2015).

Turning to other sources of revenue, the mobilisation capability of counties is limited by several factors: inadequate capacity of county government officers; legislative and regulatory restrictions set by the Treasury, and lack of a proper framework for dealing with development partners. A key issue is that Articles 138-142 of Kenya's Public Finance Management Act 2012 stipulate regulations and restrictions that greatly limit the scope of counties to borrow or attract grants. National government retains the power to determine the manner in which county governments engage with development partners, especially regarding loans that require approval by Treasury. Under such circumstances, county governments have experienced substantive challenges in attracting and negotiating the terms of alternative funding from external development partners that could supplement IFTs from national government (Langat 2016). The national government however argues that without effective controls in several areas, namely i) public finance management ii) the scope of engagement with international development partners and iii) the tax regime selected, county governments could cause macroeconomic turmoil that must be strenuously avoided ${ }^{8}$ (Tanzi 2001; Devas et al. 2008).

The result is a ham-strung system of fiscal decentralisation that makes it difficult for county governments to effectively deliver healthcare services. This is partly due to national government

\footnotetext{
7 "County governments perform dismally in revenue collection" (Okulo 2014).

${ }^{8}$ Decentralisation may reduce room for maneuver for a national government to manage the economy, increase fiduciary risks, maybe even threaten macroeconomic stability (Devas et al. 2008): http://www.keepeek.com/Digital-Asset-Management/oecd/commonwealth/governance/financing-localgovernment_9781848590076-en\#page24
} 
inefficiency, but nevertheless accountability remains squarely with county governments - at least in the eyes of the voters. The questions that arise are therefore: Who is responsible when financing for health is inadequate? and Who is accountable to citizens at the county level when they are unable to access healthcare services?

\section{Decision-making}

One argument for decentralisation has been that allowing decisions to be taken closer to beneficiaries of public 'goods' improves allocative efficiency, responsiveness of policy, and downward accountability (Rao et al. 2014). Nonetheless, in multiple cases of decentralisation in Africa, progress has been slowed or thwarted by the reluctance of central or national actors to relinquish decision-making power (Wunsch 2001; Olowu 2003).

The devolution statutes in Kenya's 2010 Constitution clearly provide for transfer of decision-making prerogatives and authority to lower levels of government - in the case of the health sector, county health management teams. This brings health system managers closer to service users and enables them to make decisions and act on them faster and more efficiently than through a centralised health system. Ochieng et al. (2015) studied the early impacts of devolution on Kenya's health sector. They found that whilst health sector stakeholders acknowledged that they had more decision-making autonomy since devolution, they still felt this autonomy was insufficient. Misconceptions and ambiguity over what decisions can be taken at what level of government are hampering decision-making at county level. County government officers argued that for decision-making to be effective, and a 'game-changer', it must include authority over the most important health sector issues: namely resources, policy and human resources management (Ochieng et al. 2015).

In fact, however, most key decision issues remain subject to regulations and policy set by national government (Ochieng et al. 2015). For instance, Kenya's Controller of Budgets (an independent national-level post) retains power to cap how much a county government decides to spend on health (Menya 2014; Lakin 2015; Omondi 2016). This is a significant limitation to the power of elected county governors, who are nevertheless accountable to citizens for the availability - or lack - of resources for health. There have been attempts by county governments to bypass this, through resolutions passed by county assemblies, but without success (Menya 2014; Lakin 2015; Omondi 2016).

A similar problem arises in the areas of policy oversight, human resources management, and procurement of health commodities. Kenya's constitution and supplementary legislation provide that whilst delivery of healthcare services is devolved and managed by county governments, oversight and development of policy remain the role of the national government (Kibui et al. 2015; Ochieng et al. 
2015). ${ }^{9}$ This has been argued to be necessary for standardisation and strategic direction, amongst other reasons (Kibui et al. 2015; Ochieng et al. 2015). However, an unintended effect of this approach is that it limits the capacity of county health management teams to design and implement innovative, contextualised health systems suitable for their particular circumstances (Ochieng et al. 2015). Whether in procurement of drugs and other health commodities, or human resources management, national standards and regulations profoundly affect decisions made at the county level (Kibui et al. 2015; Ochieng et al. 2015).

\section{Political accountability}

A rather simplistic definition of political accountability - but one which is useful here - describes it as a "specific form of relationship in which elected government officials are directly responsible to voters for their public actions including [...] the provision of public goods" (Acosta et al. 2013, p. 6).

Essentially, political accountability depends on the number of agents involved in the relationship between the governed and the governing - with the governed holding those who govern to account on promises or policy, including service delivery (Acosta et al. 2013). In simple scenarios, this only involves elected officials and voters. In more complex variations, which are more common, there are more than two agents. For example, the relationship could include competing principals - as in the case of a legislator juggling the interests of an electorate and his party position or attempting to satisfy a powerful political figure (Acosta et al. 2013). Alternatively, the relationship could include non-elected state officers, with no or few obligations to the electorate (though in theory they should feel such obligations) who wield significant power capable of influencing the endeavours of the legislator (Acosta et al. 2013).

Unsurprisingly, such variations in the number and characteristics of the agents involved in an accountability framework have significant implications for decentralised service delivery (Panday 2006; Hoffman 2006; Acosta et al. 2013). They may negatively affect the ability and/or willingness of decentralised systems to effectively deliver services (Wunsch 2001; Crook 2003; Panday 2006). In the case of Kenya's devolved health system, the division of political responsibility and accountability for service delivery between national and county governments breeds stand-offs, uncertainty and inefficiency.

The constitution transfers almost all responsibility and accountability for healthcare service delivery to county governments. Part II of the Fourth Schedule of the Constitution of Kenya 2010 lists health services as a function of county governments. Consequently, government officials at the counties are

\footnotetext{
${ }^{9}$ See Part I, Fourth Schedule, Constitution of Kenya 2010: http://kenyalaw.org/lex/rest//db/kenyalex/Kenya/The\%20Constitution\%20of\%20Kenya/docs/ConstitutionofKen уа\%202010.pdf
} 
answerable to the local electorate on the status of health facilities, services and financing. The local electorate - either directly, or indirectly through non-state actors operating on its behalf - understands this obligation and constantly demands responsive services.

Unfortunately, the existing accountability framework barely acknowledges (at least in practice) that national government and other state institutions (such as independent commissions) retain some prerogatives on health sector matters. For example, the national Treasury demands compliance with specific public finance management regulations before funds for health are transferred. Equally, the national Commission on Revenue Allocation determines the overall amounts of money sent to counties, with obvious implications for what a county can then allocate to health. Similarly, Kenya's Office of the Controller of Budgets sets expenditure ceilings that ultimately affect what is allocated at county level for health or health sub-sectors.

The net effect is a local electorate demanding accountability, answerability and responsibility for the status of healthcare from elected county government officials - but almost completely uninformed about the intricacies of the vertical relationships between local and national levels of government. County governments are caught in the middle, juggling demands from the local electorate while trying to comply with policies, standards and regulations set by national institutions that have little contact with (or sense of obligation to) that electorate.

As a result, elected county governors and members of county assemblies seek to blame the national government for poor delivery of services - sometimes even for issues which are squarely within the county mandate. The national government then seeks to exonerate itself by pointing to the constitution and supplementary legislation transferring power to local governments. The electorate does not know who to believe and meanwhile service delivery continues to suffer. And ultimately, when pharmacies are empty or nurses at the local health facility go on strike, people do not go to camp at the doorstep of the Ministry of Finance in Nairobi, the Controller of Budgets or the Commission on Revenue Allocation. They go to the governor's office demanding answers.

\section{Conclusion}

Devolution as currently practised in the health sector in Kenya involves only a partial transfer of responsibility for service delivery to county governments, which unfortunately has created unbalanced accountability relations between different levels of government. Potentially, this imbalance could undermine the many positive opportunities that devolution creates or promises. Developments over the past two years in Kenya illustrate how devolution takes a long time to deliver sustainable change and how much effort, commitment and leadership is still required to succeed. 
This paper further finds that devolution of the health function in Kenya has introduced ambiguities of responsibility and accountability for service delivery which lead to challenges of coordination between the national and county governments. A great deal of decision-making capacity and resource management authority remain at national level, making it difficult for county governments to effectively deliver healthcare services, despite shouldering the burden of accountability. Finding the right accountability and coordination mechanisms to balance relations between central/national and decentralised governments is a daunting endeavour which will require patience and continuous action but is a vital one if Kenyan citizens are to secure the responsive and effective healthcare system they deserve.

\section{Declaration of conflicting interest}

The author declared no potential conflicts of interest with respect to the research, authorship, and/or publication of this article.

\section{Funding}

The author received no financial support for the research, authorship, and/or publication of this article.

\section{References}

Acosta, A.M., Joshi, A. and Ramshaw, G. (2013) Democratic accountability and service delivery: A desk review. Stockholm: International Institute for Democracy and Electoral Assistance.

Alam, M. (ed.) (2014) Intergovernmental fiscal transfers in developing countries: Case Studies from the Commonwealth. Commonwealth Secretariat Local Government Reform Series. London: Commonwealth Secretariat.

Aljazeera (2017) Kenya doctors end strike after deal with government. Available at: http://www.aljazeera.com/news/2017/03/kenya-doctors-strike-deal-government-170314084246054.html [Accessed 05 August 2017].

Anami, L. (2015) Delay in transfer of functions affecting Constitution implementation, says Charles Nyachae. Standard Digital. Available at: https://www.standardmedia.co.ke/article/2000147930/delay-in-transferof-functions-affecting-constitution-implementation-says-charles-nyachae [Accessed 01 August 2017]

Bird, R. and Smart, M. (2001) Intergovernmental fiscal transfers: Some lessons from international experience. Paper prepared for Symposium on Intergovernmental Transfers in Asian Countries: Issues and Practices, Asian Tax and Public Policy Programme, Hitosubashi University, Tokyo, February 2001

Blair, H. (2000) Participation and accountability at the periphery: Democratic local governance in six countries. World Development, 28 (1), 21-39. https://doi.org/10.1016/S0305-750X(99)00109-6

Blore, I., Devas, N. and Slater, R. (2004) Municipalities and finance: A sourcebook for capacity building. London: Earthscan.

Boadway, R. and Shah, A. (eds.) (2007) Intergovernmental fiscal transfers: Principles and practice. Public Sector Governance and Accountability Series. Washington DC: World Bank.

Boex, J. (2009) Fiscal decentralization and intergovernmental finance reform as an international development strategy. IDG Working Paper No. 2009-06, Washington, DC: Urban Institute.

Council of Governors. (2016) The Council of Governors: Statutory annual report (2014-2015). Nairobi, Kenya: The Council of Governors.

Council of Governors. (2018) About the Council of Governors [online]. Available from: http://cog.go.ke/\# [Accessed 17 May 2018]. 
Crook, R.C. (2003) Decentralisation and poverty reduction in Africa: The politics of local-central relations. Public Administration and Development, 23, 77-88. https://doi.org/10.1002/pad.261

Delay, S. (2008) Accounting and auditing for local government. In: Devas, N., Alam, M., Delay, S., Koranteng, R.O. and Venkatachalam, P. Financing local government (pp. 101-108). Local Government Reform Series. London: Commonwealth Secretariat. https://doi.org/10.14217/9781848590076-11-en

Devas, N. (2005) The challenges of decentralization. Paper presented at the Global Forum on Fighting Corruption: Brasília, June 2005. Birmingham, England: International Development Department.

Devas, N., Alam, M., Delay, S., Koranteng, R.O. and Venkatachalam, P. (2008) Financing local government. Local Government Reform Series. London: Commonwealth Secretariat. https://doi.org/10.14217/9781848590076-en

Duncan, R. (2004) Making local governance work. Paper presented to the Pacific Regional Symposium organised by the Commonwealth Local Government Forum Pacific Project, Suva, Fiji Islands, 4-8 December 2004.

Fjeldstad, O-H., Braathen, E. and Chaligha, A. (2006) Local government reform in Tanzania 2002-2005: Summary of research findings on governance, finance and service delivery. Research on Poverty Alleviation (REPOA) Brief 6, October, Dar es Salaam, Tanzania: REPOA.

Fjeldstad, O-H., Chambas, G. and Brun, J. (2014) Local government taxation in Sub-Saharan Africa: A review and an agenda for research. CMI Working Paper WP 2014:2. Bergen: Chr. Michelsen Institute (CMI).

Hoffman, B.D. (2006) Political accountability and public service provision in Africa: Evidence from Tanzania and Zambia. Paper prepared for presentation at the Workshop in Political Theory and Policy Analysis, Indiana University, Sandiego, USA, 2006.

Institute of Certified Public Accountants of Kenya. (2015) Funding county government budgets. Working paper PPG04/2015. Nairobi, Kenya: ICPAK.

Kibui, A., Mugo, R.K., Nyaga, G., Ngesu, L., Mwaniki, I.N. and Mwaniki, B. (2015) Health policies in Kenya and the new constitution for vision 2030. International Journal of Scientific Research and Innovative Technology, 2 (1), 127-134.

Lakin, J. (2015) Who can stop counties spending what they want? The answer's blowing in the wind. The East African. Available at: http://www.theeastafrican.co.ke/oped/comment/Who-can-stop-Kenya-countiesspending-what-they-want-/434750-2645426-m6cob4/index.html [Accessed 05 August 2017].

Langat, P. (2016) Governors want approval to borrow from foreign lenders. Daily Nation. Available at: http://www.nation.co.ke/news/Counties-seek-nod-to-borrow-on-their-own/1056-302964811fj83nz/index.html [Accessed 05 August 2017].

Lessmann, C. and Markwardt, G. (2009) One size fits all? Decentralisation, corruption, and the monitoring of bureaucrats. CESifo Working Paper No. 2662. Munich: CESifo.

Maina, T., Akumu, A. and Muchiri. S. (2016) Kenya county health accounts: Summary of findings from 12 pilot counties. Washington, DC: Futures Group, Health Policy Project.

McIntyre, D. and Meheus, F. (2014) Fiscal space for domestic funding of health and other social services. Working Group on Financing, Paper 5. London: Centre on Global Health Security.

Menya, W. (2014) MCAs oppose ceiling on county budgets. Daily Nation. Available at: http://www.nation.co.ke/counties/MCAs-oppose-ceiling-on-county-budgets/1107872-238182011uq7tlz/index.html [Accessed 01 August 2017].

Muriuki, J., Thuku, M., Ndolo, M., Muraguri., Njoroge, D., Mulwa, A., Kathambara, M., Kiema, J., Foster, A.A., Asfaw, Y. and Doll, K. (2015) Kenya makes progress toward HRH commitments in a devolved health system. New York, USA: Intra Health International.

Murkomen, O.K. (2012) Devolution and the healthcare system in Kenya. Presentation at the Devolution and Healthcare consultation meeting. Nairobi Kenya, October 2012

Mwenda, A.K. (ed.) (2010) Devolution in Kenya. Prospects, challenges and the future. Nairobi, Kenya: Institute of Economic Affairs. 
Nesoba, D. (2014) Health financing incompatible with Abuja declaration. The Star. Available at: http://www.the-star.co.ke/news/2014/01/02/health-financing-incompatible-with-abujadeclaration_c876732 [Accessed 01 August 2017].

Netherlands Enterprise Agency. (2016) Kenyan healthcare sector: Opportunities for the Dutch life sciences \& health sector. Nairobi, Kenya: Embassy of the Kingdom of the Netherlands.

Ochieng, K.O., Adieno, D., Rono, K. and Ibrahim, M. (2015) Pointers to impacts of devolution on healthcare service delivery in Kenya. Nairobi, Kenya: Development Initiatives.

Okulo, L. (2014) County governments perform dismally in revenue collection. The Star. Available at: https://www.the-star.co.ke/news/2014/06/25/county-governments-perform-dismally-in-revenuecollection_c960156 [Accessed 01 August 2017].

Olowu, D. (2003) Local institutional and political structures and processes: Recent experience in Africa. Public Administration and Development, 23 (1), 41-52. https://doi.org/10.1002/pad.258

Omondi, D. (2016) Budget office now given enforcement powers in new law. Standard Digital. Available at: https://www.standardmedia.co.ke/business/article/2000224271/budget-office-now-given-enforcementpowers-in-new-law [Accessed 01 August 2017].

Otenyo, H. (2017) Nurses issued sack notice as strike enters second week. The Star. Available at: http://www.the-star.co.ke/news/2017/06/12/nurses-issued-sack-notice-as-strike-enters-secondweek_c1578614 [Accessed 05 August 2017].

Panday, P.K. (2006) Central-local relations, inter-organisational coordination and policy implementation in urban Bangladesh. The Asia Pacific Journal of Public Administration, 28 (1), 41-56. https://doi.org/10.1080/23276665.2006.10779314

Plekhanov, A. and Singh, R. (2007) How should subnational government borrowing be regulated? Some crosscountry empirical evidence. IMF Staff Papers, 53 (3).Washington DC: International Monetary Fund.

Rao, S., Scott, Z. and Alam, M. (2014) Decentralisation and local government: Topic guide (3rd ed.) Birmingham, UK: GSDRC, University of Birmingham.

Republic of Kenya. (2010) Constitution of Kenya. Nairobi, Kenya: Government Printer

Republic of Kenya. (2012) Public Finance Management Act of 2012. Nairobi, Kenya: Government Printer

Saltman, R.B., Bankauskaite, V. and Vrangbaek, K. (eds.) (2007) Decentralisation in healthcare. New York, USA: World Health Organisation: EOHPS.

Shah, A. (ed.) (2007) Local public financial management. Washington, DC: The World Bank. https://doi.org/10.1596/978-0-8213-6937-1

Smoke, P. (2015) Decentralized public management: Crafting improved analysis to facilitate better performance in developing/transitioning nations. New York, USA: New York University.

Tanzi, V. (2001) Pitfalls on the road to fiscal decentralization. Economic Reform Project Working Paper no. 19. Washington, DC: Carnegie Endowment for International Peace.

UNCDF. (2005) Delivering the goods: Building local government capacity to achieve the Millennium Development Goals: A practitioner's guide from UNCDF experience in least developed countries. New York: United Nations Capital Development Fund.

UNCDF. (2010) Pursuing the MDGs through local government. New York: United Nations Capital Development Fund.

Vrangbaek, K. (2007) Towards a typology of decentralisation in healthcare. In: Saltman, R.B., Bankauskaite, V. and Vrangbaek, K. (eds.) Decentralisation in healthcare (pp. 44-62). New York, USA: World Health Organisation: EOHPS.

Wakhisi, A. (2016) Financial crisis hits Kenyan counties as national government delay funds. Standard Digital. Available at: https://www.standardmedia.co.ke/article/2000187753/financial-crisis-hits-kenyan-countiesas-national-government-delay-funds [Accessed 05 August 2017].

Were, A. (2017) Why state is not remitting cash to counties fast enough. Business Daily Africa. Available at: http://www.businessdailyafrica.com/analysis/Why-State-is-not-remitting-cash-to-counties-fastenough/539548-3986868-vgaa3fz/index.html [Accessed 01 August 2017]. 
Wong, S. and Guggenheim, S. (2006) Community-driven development: Decentralisation's accountability challenge. Washington, DC: World Bank.

World Bank. (2011) Kenya economic update \# 5. Nairobi. Kenya: World Bank Office.

Wunsch, J. (2001) Decentralization, local governance and recentralization in Africa. Public Administration and Development, 21, 277-288. https://doi.org/10.1002/pad.185

Yilmaz, S., Beris, Y. and Serrano-Berthet, R. (2010) Linking local government discretion and accountability in decentralization. Development Policy Review, 28 (3), 259-293. https://doi.org/10.1111/j.14677679.2010.00484.x 